\title{
Study of the Protective Effect of Vitamin C on Monosodium Glutamate Induced Cardiotoxicity in Adult Male Albino Rats
}

\author{
Amira A. Wahdan ${ }^{1}$ and Mohamed M. Shareef ${ }^{2}$ \\ ${ }^{1}$ Departments of Forensic Medicine and Clinical Toxicology \\ ${ }^{2}$ Departments of Pathology \\ Faculty of Medicine, Tanta University, Tanta, Egypt.
}

\begin{abstract}
Introduction: Monosodium glutamate (MSG) is worldwide used food flavoring agent. Its safety as food additive is controversial. Vitamin $\mathrm{C}$ is a water soluble vitamin with antioxidant activities

Aim of the study: The aim of this study was to evaluate the possible toxic effect of MSG on the heart and to evaluate the potential protective effect of concomitant administration of vitamin $C$ together with MSG on the heart of adult male albino rats.

Material and methods: The current study was conducted on 60 adult male albino rats. Rats were divided into six equal groups. The first group was used as control group. Group II was treated with vitamin C $(100 \mathrm{mg} / \mathrm{kg} /$ day). Group III was treated with MSG $(100 \mathrm{mg} / \mathrm{kg} / \mathrm{day})$. Group IV was treated with MSG (4g/kg/day). Group V was treated with MSG (100mg/kg/day) together with vitamin C (100mg/kg/day). Group VI was treated with MSG (4g/kg/day) together with vitamin C $(100 \mathrm{mg} / \mathrm{kg} / \mathrm{day})$. All drugs were given orally for 45 days. The weight of the heart was recorded. The level of cardiac troponin I (cTnI) enzyme and the activity of creatine kinase $\mathrm{MB}$ (CK- MB) enzyme in serum were assessed. Histopathological examination of heart tissue was carried out.

Results: Administration of MSG led to significant increase in the heart weight with significant elevation in the serum cTnI levels and serum CK-MB activity. Sections from low dose MSG treated rats revealed cloudy swelling, while sections form high dose MSG treated rats revealed extensive cloudy swelling with fiber separation and vascular congestion. Concomitant administration of vitamin C together with MSG significantly protected against all these changes

Conclusion: It was concluded that MSG is cardiotoxic and that concomitant administration of vitamin $\mathrm{C}$ is protective against MSG cardiotoxicity.

Recommendations: The current study recommends that the use of MSG should be restricted to very small amounts and should be under supervision of health authorities. The use of vitamin $\mathrm{C}$ as a natural and cheap dietary supplement is highly recommended especially in persons who consume diets reach in flavoring agents such as MSG.
\end{abstract}

Keywords Monosodium glutamate, vitamin c, ascorbic acid, heart, cardiotoxicity.

\section{Introduction}

$\mathrm{M}$ onosodium glutamate (MSG), the sodium salt of naturally occurring (non-essential) L form glutamic acid, is a well-known food flavor enhancer. Its palatable and favorite flavor is a must in almost all Chinese and South-Asian dishes. L-glutamate is the molecule responsible for the umami taste (the $5^{\text {th }}$ basic taste in addition to saltiness, sweetness, bitterness and sourness) (Geha et al., 2000). It is added to the food either as a purified monosodium salt or as a component of a mixture of amino acids and small peptides resulting from the acid or enzymatic hydrolysis of proteins (Uneyama et al., 2009). In recent years, the consumption MSG has increased all over the world (Beyreuther et al., 2007). 
MSG was considered safe by the Food and Drug Administration (FDA) agency, but in fact it was found that MSG causes many health problems (Geha et al., 2000). Previous animal studies have concluded that MSG is toxic to different body organs such as the brain (Abass and Abd El-Haleem, 2011), liver (Ortiz et al., 2006), kidneys (Abass and Abd El-Haleem, 2011; Ortiz et al., 2006), thymus (Pavlovic et al., 2009) and reproductive system (Bojanic et al., 2009; Iamsaard et al., 2014).

In human, Morselli and Garattini (1970) said that "It has been suggested that monosodium glutamate (MSG) is responsible for the Chinese restaurant syndrome, a burning sensation in the back of the neck spreading to the forearms and to the anterior thorax, accompanied by a feeling of infraorbital pressure, tightness and substernal discomfort" but the results of their study didn't support this suggestion (Morselli and Garattini, 1970). Other studies reported a link between MSG and both overweight and hypersensitivity in the form of unpleasant reactions such as numbness, tingling, headache, muscle tightness, general weakness, and flushing (He et al., 2008; Yang et al., 1997).

Oxidative stress is considered as the mechanism of MSG induced toxicities (Singh and Ahluwalia, 2012). It occurs due to imbalance between reactive oxygen species (ROS) production and endogenous antioxidant defense mechanisms (Griendling and FitzGerald, 2003).

Vitamin C (ascorbic acid) is a water-soluble ketolactone with two ionizable hydroxyl groups (Bielski, 1982). It has an antioxidant activity as it scavenges ROS and therefore prevents oxidative damage to the important biological macromolecules, such as DNA, proteins, and lipids (Konopacka, 2004).

To the best of recent knowledge, very few researches have studied the toxic effect of MSG on the heart (Kingsley et al., 2013; Paul et al., 2012). In addition, no previous researches have evaluated the effect of concomitant administration of vitamin C with MSG on the heart. So the present study was designed to evaluate the possible toxic effect of MSG on the heart and to evaluate the potential protective effect of concomitant administration of vitamin $C$ together with MSG on the heart of adult male albino rats.

\section{Material and methods}

\section{Chemicals}

Monosodium glutamate (Universal Fine Chemicals PVT. LTD, India) and Vitamin C (Universal Fine Chemicals PVT. LTD, India) were dissolved in distilled water.

\section{Experimental animals}

This study was carried out on 60 adult male albino rats, their weight ranged from 125-150 grams. They were obtained from the animal house of the Faculty of Medicine, Tanta University, Egypt. During the study, the animals were kept in wire mesh cages with ad-libitum access to food and water. The room temperature was about $22-24{ }^{\circ} \mathrm{C}$ and the animals were exposed to $12: 12$ hours light dark cycles.

\section{Ethical considerations}

1- Experimental procedures were performed according to the guide of care and the use of laboratory animals was approved by the Ethical Committee of Faculty of Medicine, Tanta University.

2- Fewer numbers of animals estimated to offer valid results were used.

3- Painless procedures were conducted with appropriate sedation to avoid pain and stress of the animals.

\section{Experimental design}

The current work was carried out in Forensic Medicine \& Clinical Toxicology department, Tanta University. After one week of acclimatization, the animals were randomly assigned into six groups (10 rats each). All animals received their doses orally by syringe feeding method once daily for 45 days.

- Group I (Control group): received only distilled water.

- Group II (Vitamin C treated group): received vitamin $\mathrm{C}$ only in a dosage of $100 \mathrm{mg} / \mathrm{kg}$ body weight (Hashem et al., 2012).

- Group III (Low dose MSG treated group): received MSG in a dosage $100 \mathrm{mg} / \mathrm{kg}$ body weight (Maga, 1995).

- Group IV (High dose MSG treated group): received MSG in a dosage $4 \mathrm{gm} / \mathrm{kg}$ body weight (Monno et al., 1995).

- Group V (Low dose MSG with vitamin C treated group): received both low dose MSG and vitamin C (100 mg/kg body weight and 100 $\mathrm{mg} / \mathrm{kg}$ body weight respectively).

- Group VI (High dose MSG with vitamin C treated group): received both high dose MSG and vitamin C orally (4gm/ $\mathrm{kg}$ body weight and $100 \mathrm{mg} / \mathrm{kg}$ body weight respectively)

The rat's oral $\mathrm{LD}_{50}$ of MSG equals $17300 \mathrm{mg} / \mathrm{kg}$ body weight (Maga, 1995). Therefore, 100mg/ $\mathrm{kg}$ body weight equals $0.58 \%$ of the rat's oral $\mathrm{LD}_{50}$ and $4 \mathrm{gm} / \mathrm{kg}$ body weight equals $23 \%$ of the rat's oral $\mathrm{LD}_{50}$.

\section{Heart weights}

After sacrificing the animals, the hearts were removed aseptically and weighed.

\section{Sample collection}

\section{A- Blood sample}

After 6 hours fasting, the animals were anaesthetized by light ether, and while the heart was still beating, blood samples $(3 \mathrm{~mL})$ were collected in dry test tubes and allowed to coagulate at ambient temperature for 30 minutes. Serum was separated by centrifugation at $2000 \mathrm{rpm}$ for 10 minutes.

\section{B- Tissue sample}

After blood sampling, the animals were sacrificed by decapitation, the thorax was opened using ventro-median incision between the jugular notch and the xyphoid 
process. The heart was removed and stripped off of paraaotic fat and fascia and then taken for histopathological assessment.

\section{Serum Biochemical Parameters}

The collected serum was used for determination of cardiac troponin I (cTnI) level using commercially available enzyme immunoassay kits (DRG International Inc., USA). The cardiac marker enzyme creatine kinaseMB (CK-MB) activity was estimated using commercially available kits (BioSystems S.A., Spain).

\section{Histopathological Examination}

The hearts were immediately washed with saline, followed by fixation in neutral buffered formalin (10\%). The fixed tissues were embedded in paraffin, and then serial sections of $5 \mu \mathrm{m}$ thickness were cut. Each section was stained with hematoxylin and eosin ( $\mathrm{H} \& \mathrm{E})$. The slides were examined under light microscope. Photomicrographs were taken with a digital camera attached to the microscope. To avoid any possible bias, the pathologist performing the histopathological examination was not informed of the treatment assignment of the different study groups.

\section{Statistical Analysis}

Data were analyzed using SPSS software statistical computer package version 22. Statistical analyses of the biochemical data were conducted using Tukey's test. The results are presented as mean values \pm standard deviations (SD). A value of $<0.05$ was accepted as statistically significant (Dawson-Saunders and Trapp, 2001).

\section{Results}

During the period of the experiment (45 days), there were no deaths in any of the animals. Table (1) shows that the mean heart weights were increased significantly in MSG treated groups (group III and IV) compared with groups I and II.

The mean heart weight in group $\mathrm{V}$ was near the mean heart weight in groups I and II, while it was significantly lower than heart weight in group III. The mean heart weight in group VI was significantly higher than the mean heart weight in groups I and II, while it was significantly lower than heart weight in group IV.

Rats in groups III and IV showed significant elevation in the mean serum cTnI levels and serum CKMB activity when compared to groups I and II. The mean serum cTnI levels and serum CK-MB activity in group V were near those in groups I and II, while they were significantly lower than that in group III. In addition, the mean serum cTnI levels and serum CK-MB activity in group VI were significantly higher than those in groups I and II, while they were significantly lower than those in group IV (Table 1).

Examination of $\mathrm{H} \& \mathrm{E}$ stained cardiac sections by light microscope showed normal cardiac muscle fibers with cellular integrity in rats from groups I and II (photomicrograph 1\& 2). Sections from low dose MSG treated rats (group III) revealed cloudy swelling (photomicrograph 3), while sections from high dose MSG treated rats (group IV) revealed extensive cloudy swelling with fiber separation and vascular congestion (photomicrograph 4). Treatment with vitamin C (in groups V\& VI) prevented these histopathological changes completely (photomicrograph 5).

Table (1): One way analysis of variance (ANOVA) with post-hoc test (Tukey) of all studied groups (each 10 rats) as regards heart weight, CK-MB and cTN1levels.

\begin{tabular}{|c|c|c|c|c|c|c|c|c|}
\hline \multirow{2}{*}{$\begin{array}{l}\text { Parameter } \\
\text { Group }\end{array}$} & \multirow{2}{*}{$\begin{array}{l}\text { Group } I^{a} \\
(n=10)\end{array}$} & \multirow{2}{*}{$\begin{array}{l}\text { Group } I^{b} \\
(n=10)\end{array}$} & \multirow{2}{*}{$\begin{array}{l}\text { Group } \text { III }^{\mathrm{C}} \\
(\mathrm{n}=10)\end{array}$} & \multirow{2}{*}{$\begin{array}{l}\text { Group IV } \\
(n=10)\end{array}$} & \multirow{2}{*}{$\begin{array}{l}\text { Group } V^{e} \\
(n=10)\end{array}$} & \multirow{2}{*}{$\begin{array}{l}\text { Group VI } \\
(n=10)\end{array}$} & \multicolumn{2}{|c|}{ ANOVA } \\
\hline & & & & & & & $\mathbf{F}$ & $\mathbf{P}$ \\
\hline $\begin{array}{l}\text { Heart weight } \\
\text { (g) }\end{array}$ & $0.62 \pm .01^{\mathrm{cdf}}$ & $0.63 \pm .01^{\mathrm{cdf}}$ & $0.85 \pm .02^{\text {abde }}$ & $1 \pm .03^{\text {abcef }}$ & $0.65 \pm .02^{\mathrm{cdf}}$ & $0.85 \pm .02^{\text {abde }}$ & 474.08 & $<0.05^{*}$ \\
\hline $\begin{array}{l}\text { cTN1 level } \\
\text { (ng/mL) }\end{array}$ & $0.06 \pm 0.02^{\mathrm{cdf}}$ & $0.07 \pm 0.02^{\mathrm{cdf}}$ & $0.45+.08^{\text {abdef }}$ & $0.79 \pm 0.02^{\text {abcef }}$ & $0.07 \pm .02^{\mathrm{cdf}}$ & $0.61 \pm 0.03$ abcde & 596.74 & $<0.05^{*}$ \\
\hline $\begin{array}{l}\text { CK-MB } \\
\operatorname{activity}(\mathrm{U} / \mathrm{L})\end{array}$ & $94 \pm 0.19^{\text {cdf }}$ & $94.7 \pm 3.52^{\mathrm{cdf}}$ & $158.4 \pm 4.14^{\text {abdef }}$ & $258 \pm 5.44^{\text {abcef }}$ & $95.3 \pm 3.4^{\mathrm{cdf}}$ & $165.3 \pm 3.7^{\text {abcde }}$ & 2667.42 & $<0.05^{*}$ \\
\hline
\end{tabular}

$n=$ number, a-f: significant difference between groups at $p<0.05^{*}$, Data are mean \pm standard deviation, cTnI cardiac

troponin $I$, CK-MB creatine kinase $-M B, g=$ gram, $\mathrm{ng} / \mathrm{mL}=$ nanogram/ milliliter, $\bar{U} / \mathrm{L}=$ unit/ Liter. 


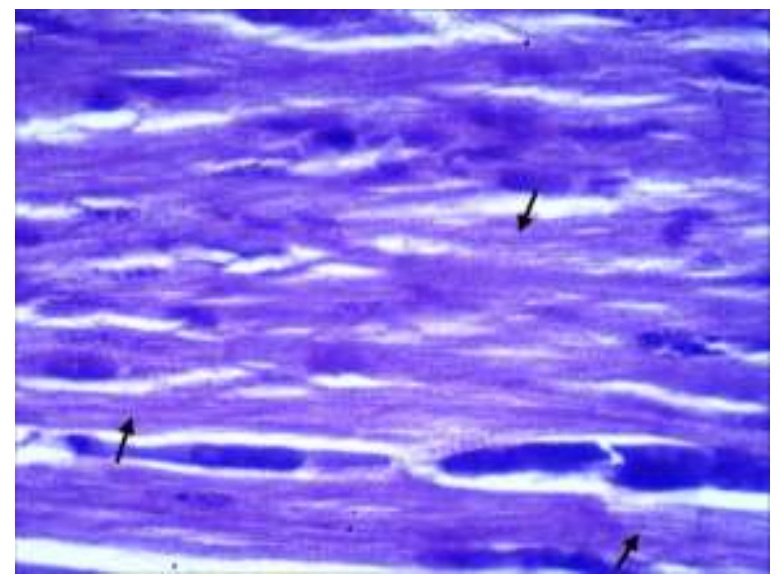

Photomicrograph (1): showing normal cardiac architecture with cross striation (arrows) from group I [H\& E x400]

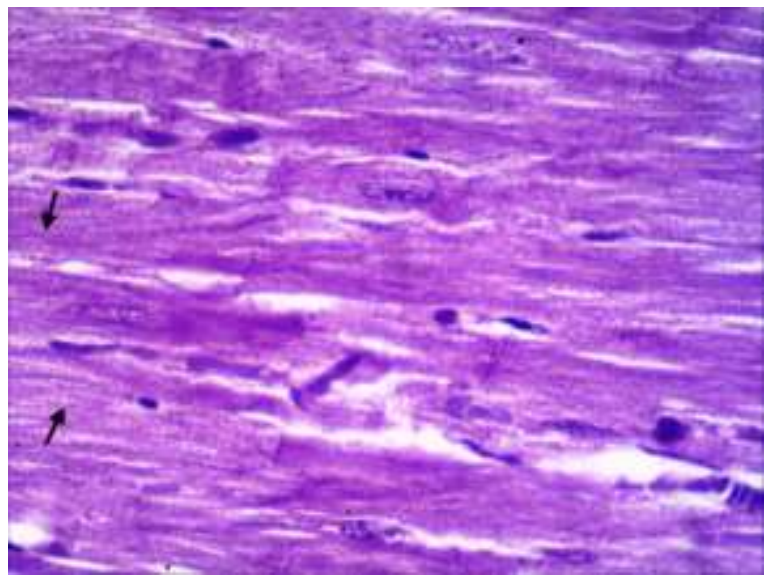

Photomicrograph (3): showing mild cloudy swelling with partial preservation of cross striation (arrows) in group III [H\& $\mathrm{E} \times 400]$

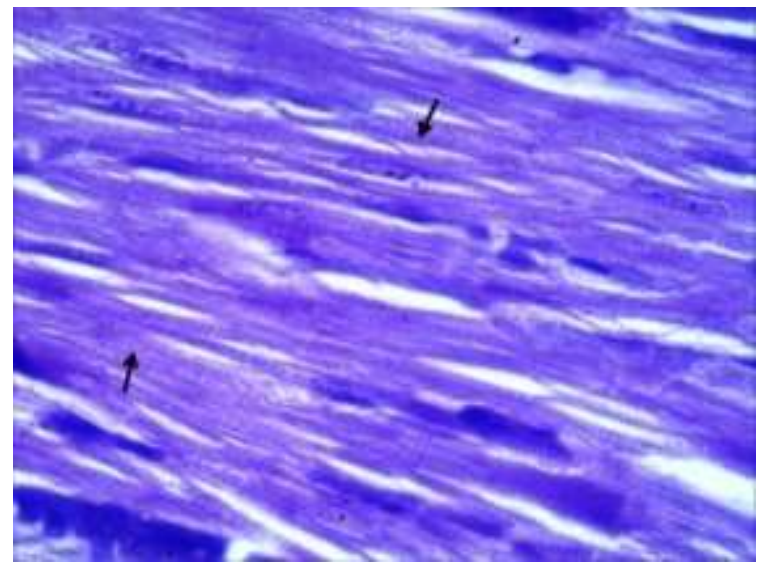

Photomicrograph (2): showing normal cardiac architecture with cross striation (arrows) from group II [H\& E x400]

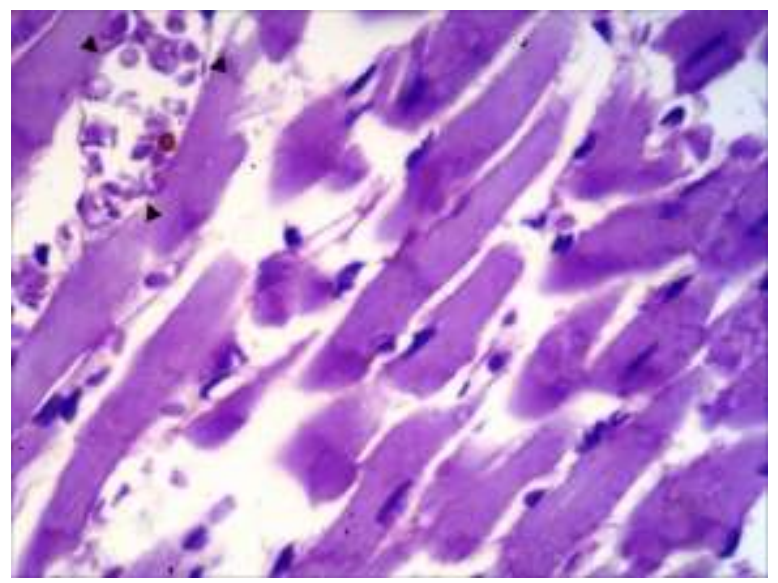

Photomicrograph (4): showing extensive cloudy swelling with loss of cross striation and vascular congestion (arrow heads) in group IV [H\& $\mathrm{E}$ x400]

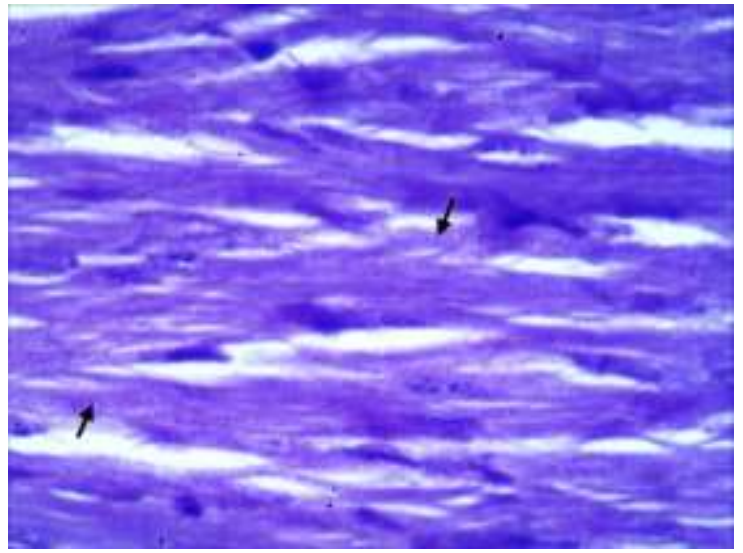

Photomicrograph (5): showing normal cardiac architecture with preservation of cross striation (arrows) from group VI [H\& E x400] 


\section{Discussion}

MSG is used as a flavor enhancer in many processed foods and drinks (Rundlett and Armstrong, 1994). At the time of its discovery, it was thought to be safe since it is a natural substance. However, unusual effects on the cardiovascular system have been described (Kingsley et al., 2013).

The current study was undertaken to investigate cardiac injury caused by oral administration of MSG in a dose of $100 \mathrm{mg} / \mathrm{Kg}$ and $4 \mathrm{gm} / \mathrm{kg}$ body weight/day for a period of 45 days. Moreover, to explore the possible protection that can be afforded by vitamin $\mathrm{C}$ with regard to its antioxidant potential.

The mean heart weights were increased significantly in MSG treated groups compared with control and vitamin $\mathrm{C}$ groups. These results were in accordance with Kingsley et al. (2013), who reported that there was a significant increase in heart weight of rats treated with MSG $8 \mathrm{mg} / \mathrm{kg}$ body weight for 28 days. The increase in heart weight suggests cardiac enlargement that involves either hypertrophy or dilatation. Hypertrophy comprises an increase in heart muscle thickness which usually occurs in only one chamber of the heart especially left ventricle (Rogers and Blundell, 1990). Heart hypertrophy occurs in response to increased cardiac stress due to increased blood pressure. Extra work of pumping blood against increased pressure causes ventricular thickening over time. Other causes of heart hypertrophy might include genetics, infection, diabetes as well as substance abuse including MSG (Kang and Izumo, 2000).

Results of the current study revealed an increase in serum cardiac troponin I (cTnI) levels in MSG treated rats. To the best of recent knowledge, there were no similar comparable previous studies that reported $\mathrm{cTnI}$ levels in serum of MSG treated rats. Nevertheless, increased cTnI could be attributed to the nature of $\mathrm{cTnI}$ where, it is a low molecular weight protein constituent of myofibrillary contractile apparatus of cardiac muscle (Alpert et al., 2000; Saravanan et al., 2013). Elevated cTnI levels can predict risk of myocardial ischemia in stress subjected patients, cardiac death and subsequent infarction (Priscilla and Prince, 2009; Sabatine et al., 2009).

Hand in hand with increased serum cTnI levels in MSG treated rats, marked elevations in serum CK-MB activity were registered in the current study. This might be related to ample concentrations of diagnostic markers of myocardial damage that is released into the extracellular fluid once myocardial cells are damaged or destroyed (Upaganlawar et al., 2009). On exposure to insufficient oxygen supply or nutrients, cardiac membrane becomes permeable or may rupture, resulting in leakage of cytosolic enzymes into the blood stream with concomitant increases of their serum concentrations (Mathew et al., 1985).
Paul et al. (2012) have recorded more or less similar elevations in serum CK-MB activity in MSG treated rats. Serum CK-MB activity is a sensitive and important diagnostic marker of myocardial injury because of its abundance in myocardial tissue and its virtual absence from most other tissues (Sabeena Farvin et al., 2004).

In the current study, cloudy swelling with fiber separation and vascular congestion were observed in MSG treated rats. Paul et al. (2012) have observed similar histopathological findings in their study.

After administration, MSG dissolves in water or saliva then dissociates into free sodium and glutamate ions. Glutamate is a principle excitatory neurotransmitter. Such glutamatergic effects are mediated primarily by ionotropic glutamate receptors (iGluRs 1-7) and on slower time scale by metabotropic glutamate receptors (mGluRs 1-8) (Nakanishi, 1992; Niswender and Conn, 2010). Among mGluRs, type 6 is unique in its sensitivity to glutamate (Nakajima et al., 1993).

These glutamate receptors were thought to be located in the central nervous system. However, further studies revealed their presence in peripheral neural and non-neural tissues (Gill and Pulido, 2005; Skerry and Genever, 2001). Differential distribution of various subtypes of glutamate receptors have been identified in the cardiac tissue of rats, monkeys and humans (Gill and Pulido, 2001; Mueller et al., 2003). Thus, these receptors may play an important role in the pathophysiology of cardiac tissue.

Continuous stimulation of metabotropic glutamate receptors may result in osmotic damage and produce oscillatory increase or intracellular mobilization of calcium stores (Bittigau and Ikonomidou, 1997; Miglio et al., 2005). Consequently, $\mathrm{Ca}^{2+}$ homeostasis imbalance triggers the activation of several enzyme pathways and signaling cascades such as calmodulin, phospholipases, protein kinases, proteases, protein phosphatases and nitric acid synthases and leads to the generation of free radicals (Gill and Pulido, 2001).

Cardiotoxic effects of MSG might be due to the capacity of MSG to induce oxidative stress by increasing the lipid peroxidation and decreasing the activity of antioxidant defense systems in the cardiac tissue (Paul et al., 2012; Singh and Ahluwalia, 2012).

Vitamin C is considered the most important water soluble antioxidant in extracellular fluids (Singh et al., 2004). It might neutralize the oxygen free radicals generated in the aqueous phase before lipid peroxidation was initiated. Thus, it might scavenge oxygen free radicals generated by stimulation of both ionotropic and metabotropic glutamate receptors (Gill and Pulido, 2001).

Therefore, the current study has demonstrated the protective effect of vitamin $\mathrm{C}$ on cardiac damage induced by MSG oral administration. Such cardio- 
protective effect was manifested by conservation of all parameters (including the heart weights, the cardiac muscle fiber architecture, serum $\mathrm{cTnI}$ levels and serum CK-MB activity) tested in vitamin C treated animals more or less near those in control groups.

Several studies have supported the protective role of vitamin C against MSG-induced oxidative stress. Farombi and Onyema (2006) have observed significant improvement in lipid peroxidation parameters in both liver and kidney of rats. Moreover, they suggested cerebral cortical protection by vitamin $\mathrm{C}$ against oxidative stress induction by MSG. Furthermore, Pavlovic and Sarac (2010) have reported significant restoration of MSG induced oxidative damage and apoptosis in the thymus by vitamin $\mathrm{C}$.

\section{Conclusion}

From the results of this study, it was concluded that MSG has cardiotoxic effects and that concomitant administration of vitamin $\mathrm{C}$ along with MSG is protective against MSG induced cardiotoxicity.

\section{Recommendations}

The current study recommends that the use of MSG as a flavoring agent in foods should be restricted to very small amounts and should be under supervision of health authorities. In addition the use of vitamin $\mathrm{C}$ as a natural and cheap dietary supplement is highly recommended especially in peoples who consume diets reach in flavoring agents such as MSG.

\section{References}

Abass MA and Abd El-Haleem MR (2011): Evaluation of monosodium glutamate induced neurotoxicity and nephrotoxicity in adult male albino rats. Journal of American Science. 7: 264-276.

Alpert JS, Thygesen K, Antman E et al., (2000): Myocardial infarction redefined-a consensus document of the Joint European Society of Cardiology/ American College of Cardiology Committee for the redefinition of myocardial infarction. Journal of the American College of Cardiology. 36: 959-969.

Beyreuther K, Biesalski HK, Fernstrom JD et al., (2007): Consensus meeting: Monosodium glutamate an update. Eur J Clin Nutr. 61: 304-313.

Bielski BHJ (1982): Chemistry of ascorbic acid radicals. In: Ascorbic acid: Chemistry, metabolism, and uses. Seib PA and Tolbert BM (eds), American Chemical Society, Washington D.C, pp: 81-100.

Bittigau P and Ikonomidou C (1997): Glutamate in neurologic diseases. J Child Neurol. 12: 471485.

Bojanic V, Bojanic Z, Najman S et al., (2009): Diltiazem prevention of toxic effects of monosodium glutamate on ovaries in rats. Gen Physiol Biophys. 28: 149-154.

Dawson-Saunders B and Trapp R (2001): Basic and clinical biostatics. Dawson-Saunders $\mathrm{B}$ and Trapp R (eds), 3rd ed., McGrow Hill McGrow Hill Medical Publishing Division.
Farombi EO and Onyema OO (2006): Monosodium glutamate-induced oxidative damage and genotoxicity in the rat: Modulatory role of vitamin C, vitamin E and quercetin. Hum Exp Toxicol. 25: 251-259.

Geha RS, Beiser A, Ren C et al., (2000): Review of alleged reaction to monosodium glutamate and outcome of a multicenter double-blind placebocontrolled study. J Nutr. 130: 1058s-1062s.

Gill S and Pulido O (2005): Glutamate receptors in peripheral tissues: Distribution and implications for toxicology. In: Glutamate receptors in peripheral tissue: Excitatory transmission outside the cns. Gill S and Pulido $\mathrm{O}$ (eds), Kluwer, Academic/Plenum, New York, pp: 326.

Gill SS and Pulido OM (2001): Glutamate receptors in peripheral tissues: Current knowledge, future research, and implications for toxicology. Toxicol Pathol. 29: 208-223.

Griendling KK and FitzGerald GA (2003): Oxidative stress and cardiovascular injury: Part II: Animal and human studies. Circulation. 108: 20342040.

Hashem HE, El-Din Safwat MD and Algaidi S (2012): The effect of monosodium glutamate on the cerebellar cortex of male albino rats and the protective role of vitamin $\mathrm{C}$ (histological and immunohistochemical study). J Mol Histol. 43: 179-186.

He K, Zhao L, Daviglus ML et al., (2008): Association of monosodium glutamate intake with overweight in chinese adults: The intermap study. Obesity (Silver Spring). 16: 1875-1880.

Iamsaard S, Sukhorum W, Samrid R et al., (2014): The sensitivity of male rat reproductive organs to monosodium glutamate. Acta Med Acad. 43: 39.

Kang PM and Izumo S (2000): Apoptosis and heart failure: A critical review of the literature. Circ Res. 86: 1107-1113.

Kingsley OA, Jacks TW, Amaza DS et al., (2013): The effect of monosodium glutamate (MSG) on the gross weight of the heart of albino rats. Sch J App Med Sci. 1: 44-47.

Konopacka M (2004): Role of vitamin c in oxidative DNA damage. Postepy Hig Med Dosw (Online). 58: 343-348.

Maga JA (1995): Flavor potentiators. In: Food additives toxicology. Maga JA and Tu AT (eds), Marcel Dekker, New York, pp: 396.

Mathew S, Menon PVG and Kurup PA (1985): Effect of administration of vitamin a, ascorbic acid and nicotinamide adenine dinucleotide and flavine adenine nucleotide on severity of myocardial infarction induced by isoproterenol in rats. Indian Journal of Experimental Biology. 23: 500-504. 
Miglio G, Varsaldi F, Dianzani C et al., (2005): Stimulation of group I metabotropic glutamate receptors evokes calcium signals and c-jun and c-fos gene expression in human $\mathrm{T}$ cells. Biochem Pharmacol. 70: 189-199.

Monno A, Vezzani A, Bastone A et al., (1995): Extracellular glutamate levels in the hypothalamus and hippocampus of rats after acute or chronic oral intake of monosodium glutamate. Neurosci Lett. 193: 45-48.

Morselli PL and Garattini S (1970): Monosodium glutamate and the chinese restaurant syndrome. Nature. 227: 611-612.

Mueller RW, Gill SS and Pulido OM (2003): The monkey (Macaca fascicularis) heart neural structures and conducting system: An immunochemical study of selected neural biomarkers and glutamate receptors. Toxicol Pathol. 31: 227-234.

Nakajima Y, Iwakabe H, Akazawa C et al., (1993): Molecular characterization of a novel retinal metabotropic glutamate receptor mGluR6 with a high agonist selectivity for 1-2-amino-4phosphonobutyrate. J Biol Chem. 268: 1186811873.

Nakanishi S (1992): Molecular diversity of glutamate receptors and implications for brain function. Science. 258: 597-603.

Niswender CM and Conn PJ (2010): Metabotropic glutamate receptors: Physiology, pharmacology, and disease. Annu Rev Pharmacol Toxicol. 50: 295-322.

Ortiz GG, Bitzer-Quintero OK, Zarate CB et al., (2006): Monosodium glutamate-induced damage in liver and kidney: A morphological and biochemical approach. Biomed Pharmacother. 60: 86-91.

Paul S, Mohanan A, Varghese MV et al., (2012): Ameliorative effect of alpha-tocopherol on monosodium glutamate-induced cardiac histological alterations and oxidative stress. J Sci Food Agric. 92: 3002-3006.

Pavlovic V and Sarac M (2010): The role of ascorbic acid and monosodium glutamate in thymocyte apoptosis. Bratisl Lek Listy. 111: 357-360.

Pavlovic V, Pavlovic D, Kocic G et al., (2009): Ascorbic acid modulates monosodium glutamate induced cytotoxicity in rat thymus. Bratisl Lek Listy. 110: 205-209.

Priscilla DH and Prince PS (2009): Cardioprotective effect of gallic acid on cardiac troponin-t, cardiac marker enzymes, lipid peroxidation products and antioxidants in experimentally induced myocardial infarction in wistar rats. Chem Biol Interact. 179: 118-124.

Rogers PP and Blundell JE (1990): Umami and appetite: Effects of monosodium glutamate on hunger and food intake in human subject. Phsiol Behav. 486: 801-804.

Rundlett KL and Armstrong DW (1994): Evaluation of free D-glutamate in processed foods. Chirality. 6: 277-282.

Sabatine MS, Morrow DA, de Lemos JA et al., (2009): Detection of acute changes in circulating troponin in the setting of transient stress testinduced myocardial ischaemia using an ultrasensitive assay: Results from TIMI 35. Eur Heart J. 30: 162-169.

Sabeena Farvin KH, Anandan R, Kumar SH et al., (2004): Effect of squalene on tissue defense system in isoproterenol-induced myocardial infarction in rats. Pharmacol Res. 50: 231-236.

Saravanan G, Ponmurugan P, Sathiyavathi M et al., (2013): Cardioprotective activity of amaranthus viridis linn: Effect on serum marker enzymes, cardiac troponin and antioxidant system in experimental myocardial infarcted rats. International Journal of Cardiology. 165: 494498.

Singh K and Ahluwalia P (2012): Effect of monosodium glutamate on lipid peroxidation and certain antioxidant enzymes in cardiac tissue of alcoholic adult male mice. J Cardiovasc Dis Res. 3: 12-18.

Singh RP, Sharad S and Kapur S (2004): Free radicals and oxidative stress in neurodegenerative diseases: Relevance of dietary antioxidants. JIACM. 5: 218-225.

Skerry TM and Genever PG (2001): Glutamate signalling in non-neuronal tissues. Trends Pharmacol Sci. 22: 174-181.

Uneyama H, Kawai M, Sekine-Hayakawa Y et al., (2009): Contribution of umami taste substances in human salivation during meal. J Med Invest. 56 Suppl: 197-204.

Upaganlawar A, Gandhi C and Balaraman R (2009): Effect of green tea and vitamin E combination in isoproterenol induced myocardial infarction in rats. Plant Foods Hum Nutr. 64: 75-80.

Yang WH, Drouin MA, Herbert M et al., (1997): The monosodium glutamate symptom complex: Assessment in a double-blind, placebocontrolled, randomized study. J Allergy Clin Immunol. 99: 757-762. 


\section{الملخص العربي}

\section{دراسة التأثير الوقائي لفيتامين ج على التسمم القلبي الناتج عن جلوتامات أحادي الصوديوم في ذكور الجرذان

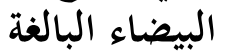

\section{أميرة أمين وهدان ا و محمد مصطقى شريف}

المقدمة: الجلوتامات أحادية الصوديوم هي منكه غذائي يستخدم في جميع أنحاء العالم. و واماها على الصحة كإضافات غذائية مثير للجدل. فيتامين ج هو فيتامين له دور مضاد للأكسدة.

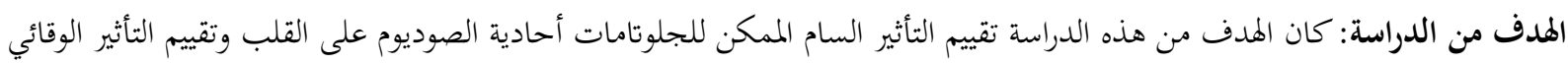
المتمل لإعطاء فيتامين ج مصاحبا للجلوتامات أحادية الصوديوم على القلب في ذكور الجرذان البيضاء البالغة مواد و طرق البحث: أجريت الدراسة الحالية على ـاج من ذكور الجرذان البيضاء البالغة. تم تقسيم الجرذان إلى ست بجموعات متساوية.

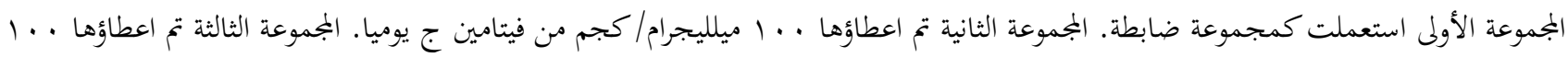

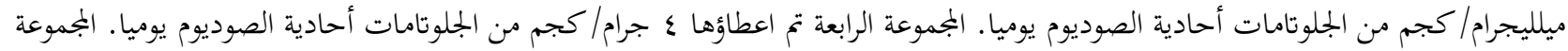

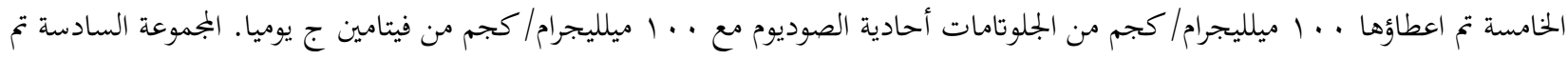

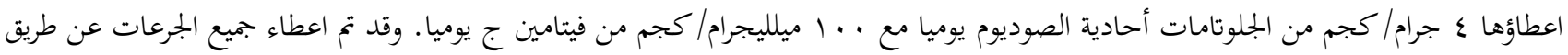

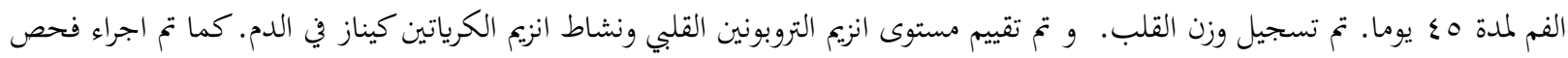
هستوباثولوجي لأنسجة القلب.

النتائج: أدى اعطاء الجلوتامات أحادية الصوديوم إلى زيادة ملحوظة في وزن القلب مع ارتفاع ملحوظ في مستويات انزيم التروبونين القببي

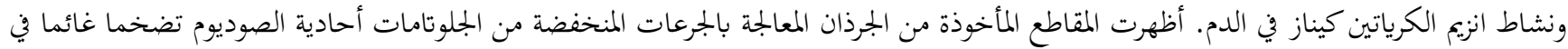
انسجة القلب، في حين اظهرت المقاطع المأخوذة من الجرذان المعالجة بالجرعات المرتفعة تضخما غائما واسعا مع انفصال في الألياف واحتقان في الأوعية الدموية. اعطاء فيتامين ج مصاحبا للجلوتامات أحادية الصوديوم حمى بشكل ملحوظ من جميع هذه التغيرات.

الاستنتاج: تم استنتاج ان الجلوتامات أحادية الصوديوم سامة للقلب و ان اعطاء فيتامين ج مصاحبا لها يقي من سميتها للقلب.

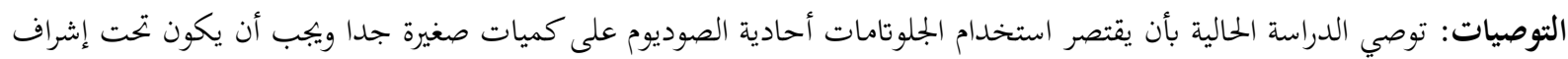
السلطات الصحية .كما ينصح بشدة باستخدام فيتامين ج كمكمل غذائي طبيعي ورخيص خاصة في الاشخاص الذين يستهلكون الوجبات الغذائية الغنية بالمنكهات مثل الجلوتامات أحادية الصوديوم. 